DOI 10.15290/cnisk.2017.02.03.03

DOC. DR LUBOU KOZIK

orcid.org/0000-0003-1243-1046

Białoruski Uniwersytet Państwowy w Mińsku

\title{
Kobiety w ruchach społecznych Białorusi (1919-1991). Stan badań i perspektywy
}

\section{Streszczenie}

W historiografii białoruskiej historia kobiet jako samodzielny kierunek $\mathrm{w}$ badaniach naukowych pojawiła się dopiero w połowie lat dziewięćdziesiatych XX stulecia. W tym czasie zaczynano organizować konferencje naukowe, ukazały się pierwsze publikacje poświęcone temu zagadnieniu. Historia kobiet nigdy jednak nie budziła dużego zainteresowania wśród naukowców. Badania wciąż mają charakter przyczynkarski, w przeszłości zaś służyły upowszechnianiu opinii o sukcesach partii komunistycznej w rozwiązaniu problemu równości płci. Afirmacja idei równouprawnienia kobiet eliminowała $z$ publicznego dyskursu ten problem, a tym samym i temat badań. Spośród wydanych na Białorusi opracowań najwięcej dotyczy zainicjowanej w okresie międzywojennym przez struktury partii aktywizacji społecznej kobiet. Współcześni autorzy zwracaja $z$ kolei uwage na ambiwalentny stosunek terenowych działaczy komunistycznych wobec problemu awansu społecznego kobiet, a także brak zainteresowania ze strony kobiet na wsi zmiana swojego tradycyjnego statusu.

Słowa kluczowe: historia kobiet, Białoruś, historiografia, ruch społeczny, wydziały kobiece, zjazdy delegatek 


\title{
WOMEN IN BELARUSIAN SOCIAL MOVEMENTS IN 1919-1991. THE PRESENT STATE OF RESEARCH AND PERSPECTIVES
}

\begin{abstract}
In Belarusian historiography, the history of women as an independent research direction appears only in the middle 1990-ies. Since that time, some scientific conferences have been held and some special editions dedicated to the history of women in Belarus. It should be noted that the researchers are not interested in the women's history by itself there are very few publications on it. The history of women's participation in public life of the Byelorussian SSR can be divided into three periods: interwar, the Second World War and after the Second World War. The foundation of the women's councils and the congresses of delegates and their activity in the interwar period are better described. The authors note that the Belarusian authorities expected that the activity of these institutions would lead to the changes in the social position of women increasing their role in public life. The women's participation in other social organizations and social movements in the Byelorussian SSR are shallowly studied as well as their participation in the Belarusian collaborating organizations during the Second World War.
\end{abstract}

Keywords: women's history, Belarus, historiography, social movement, women's councils, congresses of delegates

Badania nad problematyką kobiecą na Białorusi mają dość krótka historię. W historiografii zachodniej tematyka ta pojawiła się jeszcze w latach siedemdziesiatych XX w. i od tego czasu zajmuje trwałe miejsce w nauce. W historiografii białoruskiej ten kierunek badań zaczął się formować dopiero w połowie lat dziewięćdziesiątych. Wtedy pojawiły się pierwsze publikacje, w których były rozważane problemy dotyczace metodologii badań historii kobiet, pokazywano, w jaki sposób temat traktuje historiografia zachodnia i jak na tym tle wyglądaja analizy w historiografii białoruskiej ${ }^{1}$.

\footnotetext{
1 Zob. zwłaszcza rozdział: Historyja żanczyn jak histaryjahraficznaja prablema [w:] Histaryjahrafija historyi Biełarusi kanca XVIII - paczatku XX: zdabytki, prablemy, pierspiektywy, red. W.W. Janouskaja, Minsk 2006, s. 404-427.
} 
Zainteresowaniu tematem sprzyjały organizowane na Białorusi międzynarodowe konferencje naukowe: „Narodowo-historyczne źródła ruchu kobiet na Białorusi: przeszłość i perspektywy” (1996), „Od historii do historii” (1998), „Kobieta. Edukacja. Demokracja” (1998-2007), „Kobiety w drugiej wojnie światowej: historia walki i trwania" (2006). Innego rodzaju impulsem wspierajacym badania kobiece było powołanie w 1997 r. Centrum Badań nad Kulturowymi Aspektami Ludzkiej Płciowości w Europejskim Uniwersytecie Humanistycznym w Mińsku².

W tym czasie zaczęły się także ukazywać liczne publikacje dotyczace historii kobiet, takie jak Kobiety $w$ historii: szanse na bycie docenionymi $i^{3}$, Kobiety na krańcach Europy ${ }^{4}$, oraz zbiory materiałów pokonferencyjnych. W 1997 r. na Białorusi ukazała się, wydana przy wsparciu ONZ, książka Kobiety Białorusi w zwierciadle epoki $i^{5}$, która pokazuje wszystkie ówczesne kierunki badań nad problematyka kobieca.

Badania $z$ lat dziewięćdziesiątych nie znalazły uznania tradycyjnych środowisk naukowych. Nowych badaczy dziejów kobiet na Białorusi było zresztą niewielu, a tym, co ich wyróżniało, było przeorientowanie zainteresowań w kierunku kulturowych aspektów kobiecej płciowości ${ }^{6}$. $Z$ czasem jeden $z$ tych nielicznych, Albert Jakiełła, doszedł do wniosku, że studia dotyczace kulturowych aspektów kobiecej płciowości były w realiach białoruskich bardziej wynikiem rozszerzenia kontaktów $z$ badaczami zagranicznymi niż własnych naukowych poszukiwań. Niewielkie zainteresowanie tak ujmowaną tematyką kobieca tłumaczył brakiem liczącego się ruchu feministycznego, jak też ogólnie społecznego zapotrzebowania

2 Centr giendiernych issledowanij Jewropiejskogo gosudarstwiennogo uniwiersitieta: http://bit.ly/2hIUULA.

3 Żenszcziny $w$ istorii: wozmożnost' byt' uwidiennymi, red. I. Czikałowa, Minsk 2001, t. 1; t. 2, 2002; t. 3, 2004.

4 Żenszcziny na kraju Jewropy, red. E. Gapowa, Minsk 2003.

5 Żenszcziny Biełarusi w zierkale epochi: nacyonalnyj otczet, Minsk 1997.

6 Zob. zwłaszcza: N. Skułak, Istorija żenszczin Biełarusi w sowriemiennoj otieczestwiennoj istoriografii [w:] Giendier i problemy kommunikatiwnogo powiedienija, Połock 2005, s. 42-44; I. Czikałowa, Intiegracyja giendiernoj problematiki $w$ biełorusskoje akadiemiczeskoje prostranstwo: niekotoryje priedwaritielnyje itogi [w:] Żenszczina. Obszczestwo. Obrazowanije, Minsk 2008, s. 30-42. 
na wiedzę dotycząca roli kobiet w historii Białorusi ${ }^{7}$. Także Natalia Anofranka jako jedna $z$ przyczyn stagnacji badań kobiecych na Białorusi oraz $\mathrm{w}$ innych państwach postsowieckich widzi w uprzedzeniach środowiska historyków do podejmowania studiów związanych $z$ problematyka feministyczną ${ }^{8}$.

Wśród pozostałych przyczyn braku zainteresowania historia kobiet można wymienić tradycję $z$ czasów sowieckich, kiedy historia była rozpatrywana tylko $z$ punktu widzenia pozycji klasowych. Pewny wpływ na to miało stanowisko władz przyjęte w 1930 r., mówiące, że problem kobiet w ZSRS został rozwiązany poprzez ich faktyczne równouprawnienie $z$ mężczyznami. Nie było problemu, nie było zatem tematu badań.

Konstatując, można stwierdzić, że historia kobiet nie nale$\dot{z} y$ do tych budzacych zainteresowanie na Białorusi. Tym niemniej w różnych ośrodkach naukowych podejmowane sa pewne inicjatywy badawcze. W ostatnich latach odbywały się obrony rozpraw doktorskich, w których tematem były różne aspekty historii kobiet oraz ich obecność życiu publicznym. Pozwala to mieć nadzieję, że tematyka ta stanie się $\mathrm{w}$ niedługim czasie zauważalnym kierunkiem badań w historiografii białoruskiej.

Analizujac faktyczny i historiograficzny materiał o udziale kobiet w życiu publicznym na Białorusi, można wydzielić kilka bloków problemowo-chronologicznych: 1) udział kobiet w ruchu społecznym w okresie międzywojennym, 2) kobiety podczas Wielkiej Wojny Ojczyźnianej, gdy zderzyły się narodowa i komunistyczna wizja rozwoju Białorusi, 3) kobiety w ruchu politycznym i społecznym w powojennej Białorusi.

Już na początku lat dwudziestych sowieccy badacze zwracali uwagę na zmianę $\mathrm{w}$ pozycji społecznej kobiet w ZSRS, co w konsekwencji zachęciło ich do podjęcia bardziej wnikliwych badań. W tamtych czasach mogły jednak ukazywać się publikacje przede wszystkim o charakterze propagandowym, gdzie pokazywa-

\footnotetext{
A. Jakiełła, Giendiernaja istorija $w$ biełorusskoj istoriografii. Wozniknowienije i razwitije, „Wiesnik Hrodzienskaha dziarżaunaha uniwiersiteta” 2007, seria 1, nr 3, s. 32.

8 Historyja żanczyn jak histaryjahraficznaja prablema..., s. 412.
} 
no politykę bolszewików w rozwiązywaniu problemu dyskryminacji kobiet, dużo pisano o udziale kobiet w życiu gospodarczym i społecznym kraju9 . Bardzo szybko jednak ówczesne zainteresowanie historią kobiet, a szczególnie ich rolą i miejscem w socjalistycznym społeczeństwie, zaczęło zanikać.

Badania bezpośrednio na gruncie białoruskim pojawiły się dopiero w końcu lat pięćdziesiątych. Były to najczęściej próby oceny roli kobiet $\mathrm{w}$ budownictwie socjalizmu w okresie międzywojennym $^{10}$. Badacze zwracali uwage na przemiany w statusie społecznym kobiet przed rewolucja październikowa i po dojściu do władzy bolszewików, podkreślając, że władza sowiecka na poziomie prawnym ogłosiła ekonomiczne, polityczne i socjalne równouprawnienie kobiet, zmieniwszy tym samym ich pozycję społeczną.

W tym czasie zwracano uwagę na działalność wydziałów kobiecych, które powstały przy komitetach partyjnych i prowadziły pracę wychowawczo-ideologiczna szczególnie na prowincji. $Z$ jednej strony była to polityczna edukacja kobiet zgodna $z$ duchem ideologii sowieckiej, a $z$ drugiej aktywizacja do ich udziału w życiu publicznym. W zwiąku $z$ tym upowszechniono zebrania delegatek i organizacje specjalnych konferencji dla kobiet. Innymi formami pracy ukierunkowanymi na podwyższenie pozycji społecznej kobiet były walka $z$ analfabetyzmem, prowadzenie pracy polityczno-oświatowej, druk kobiecych periodyków.

Badacze białoruscy przeważnie zwracali uwagę na rolę Komunistycznej Partii Białorusi w organizacji pracy z kobietami

\footnotetext{
9 Zob. zwłaszcza: A.M. Dułau, Stanowiszcza żanczyn u BSSR 1920-1930-ch hh.: biełaruskaja histaryjahrafija, „Wiesnik Wiciebskaha dziarżaunaha uniwiersiteta imia P.M. Maszerawa” 2002, nr 2, s. 12.

10 W.W. Sorokina, Wowleczenije żenszczin-kriestjanok $w$ obszczestwienno-politiczeskuju żyzn' biełorusskoj dieriewni w wosstanowitielnyj pieriod (1921-1925 gg.), „Uczenyje zapiski Minskogo piedagogiczeskogo instituta im. A.M. Gor'kogo” 1957, t. 8, s. 23-47; Eadem, Rol żenszczin-kriestjanok $w$ obszczestwienno-politiczeskoj i kulturnoj żyzni biełorusskoj dieriewni $w$ wosstanowitielnyj pieriod (19211925 gg.), Minsk 1958; E.N. Zachwatajewa, Proizwodstwiennaja i obszczestwienno-politiczeskaja diejatielnost' żenszczin Sowietskoj Biełorussii w gody wtoroj piatiletki (1933-1937 gg.), Minsk 1958; Eadem, Żenszcziny Sowietskoj Biełorussii - aktiwnyje stroitieli kommunizma, Minsk 1960.
} 
w okresie międzywojennym ${ }^{11}$. Podkreślali, że działalność partii wśród kobiet przewidywała zróżnicowane podejście do poszczególnych warstw społecznych i grup kobiet, a także kształtowanie wśród nich postaw oddania partii komunistycznej, aktywnego udziału w budownictwie socjalistycznym ${ }^{12}$.

Wydane w Białoruskiej Socjalistycznej Republice Sowieckiej (BSRS) prace były napisane zgodnie $z$ obowiąująca metodologia marksistowsko-leninowską oraz interpretacją dziejów $z$ pozycji klasowych. Wynikiem tego była jednoznacznie pozytywna ocena pracy partii w sprawie aktywizacji kobiet do życia społeczno-politycznego republiki. Stała cecha propagandy do 1991 r. było niezmienne podkreślanie równouprawnienia mężczyzn i kobiet w państwie socjalistycznym. Takie hasła zawarte były także w naukowych opracowaniach ${ }^{13}$.

Sytuacja zmieniła się dopiero w latach dziewięćdziesiątych, gdy zaczęto odchodzić od powyższej interpretacji dziejów i w sposób bardziej obiektywny opisywać rzeczywistość. Na przykładzie publikacji Anatola Dułowa dobrze widać zmianę narracji o społecznej roli kobiet w BSRS w okresie międzywojennym ${ }^{14}$. Autor stwier-

11 M.G. Diubakowa, Bor'ba Kommunisticzeskoj partii Biełorussii za wowleczenije żenszczin riespubliki $w$ promyszlennuju $i$ obszczestwienno-politiczeskuju diejatielnost' (1926-1932 gg.), Minsk 1961; A. Komarow, Nowyje jawlenija $w$ obszczestwiennom i siemiejnom bytu trudiaszczichsia Sowietskoj Biełorussii (1917-1929 gg.), Minsk 1969; M.S. Portnowa, Diejatielnost' Kompartii Biełorussii po wowleczeniju żenszczin dieriewni $w$ kołchoznoje stroitielstwo (1929-1934 gg.), Minsk 1972; T.G. Bobkowa, Diejatielnost' KPB po razwitiju trudowoj i obszczestwienno-politiczeskoj aktiwnosti żenszczin $w$ wosstanowitielnyj pieriod (19211925 gg.), Minsk 1983.

12 T.G. Bobkowa, op. cit., s. 11.

${ }^{13}$ Na przykład: A. Us, Żenszcziny sowietskoj Biełorussii, Minsk 1948; Eadem, Szto dała Kastrycznickaja rewalucyja żanczynam Biełarusi, Minsk 1958; A. Zachwatajewa, Żenszcziny Sowietskoj Biełorussii - aktiwnyje stroitieli kommunizma, Minsk 1960; W bor'bie i trudie: uczastije żenszczin Biełorussii $w$ riewolucyonnom dwiżenii, socyalisticzeskom i kommunisticzeskom stroitielstwie, red. T.T. Dmitrijewa, Minsk 1977.

14 A.N. Dułow, Żenszcziny Sowietskoj Biełarusi w obszczestwienno-politiczeskoj żyzni i matierialnom proizwodstwie (20-je gody XX wieka), Minsk 2006; Idem, Stanowiszcza żanczyn u BSSR 1920-1930-ch hh.: biełaruskaja histaryjahrafija, „Wiesnik Wiciebskaha dziarżaunaha uniwiersiteta imia P.M. Maszerawa” 2002, nr 2, s. 12-16; Idem, Stanowlenije żenskogo dwiżenija w BSSR (1920-je gg.) [w:] Giendier i problemy kommunikatiwnogo powiedienija, Połock 2007, s. 78-79; 
dził, że nowy porządek społeczny zakładający równość płci, który pojawił się w BSRS w latach dwudziestych, był uwarunkowany polityka partyjno-państwową skierowaną na poszerzenie udziału kobiet w życiu publicznym. W tym celu wydano odpowiednie akty prawne oraz zbudowano aparat propagandowo-ideologiczny.

Dułow (Dułau) zwrócił także uwagę na wydziały kobiece przy partyjnych organizacjach i ich działalność w terenie, podkreślając znaczenie w przezwyciężeniu stereotypów w sprawie roli i miejsca kobiety w społeczeństwie. Wśród głównych trudności w pracy tych wydziałów w terenie wymienił niejednoznaczny stosunek kierownictwa partyjnego do potrzeby aktywizacji społecznej kobiet, obojętność i brak zaangażowania samych kobiet, brak odpowiedniego przygotowania organizatorów. Wraz z początkiem kolektywizacji działalność wydziałów kobiecych zaczęła zanikać. Dułow uważa, że przyczyna tego był wzrost niezadowolenia wiejskich kobiet tymi przemianami oraz próby wpływania zebrań kobiecych na decyzje czynników partyjno-państwowych. Jednocześnie autor zwraca uwage, że kontynuowano konferencje i zjazdy kobiet, podczas których przekonywano do wstępowania do kołchozów.

Inne problemy dotyczace historii kobiet przedstawione zostały w pracach Iryny Łaurynouskiej ${ }^{15}$ i Illi Kurkowa ${ }^{16}$. W pracach

Idem, Dielegatskije sobranija kak sriedstwo politiczeskoj socyalizacyi żenszczin Sowietskoj Biełorussii (1920-je - naczało 1930-ch gg.), „Uczenyje zapiski Uczrieżdienija obrazowanija "WGU im. P. M. Maszerowa" 2009, t. 8, s. 19-30; G.N. Jakowlewa, A.N. Dułow, Żenszcziny Witiebszcziny $w$ pieriod modiernizacyi $1930-c h$ godow, „Żenszcziny w istorii: wozmożnost' byt' uwidiennymi” 2001, t. 1, s. 304310; A.N. Dułow, Stanowlenije i razwitije żenskogo dwiżenija $w$ BSSR $w$ mieżwojennyj pieriod [w:] Hramadskija ruchi i palitycznyja partyi u Biełarusi, red. I. Koukiel, Hrodno 2009, s. 202-206.

15 I. Ławrinowskaja, Obszczestwiennyj status żenszcziny $w$ Biełarusi $w$ pierwoj trieti XX wieka [w:] Biełarus' u histarycznaj retraspiektywie XIX-XX stahoddziau: etnakulturnyja i nacyjanalna-dziarżaunyja pracesy: zbornik nawukowych artykułau: w 2 czast., red. W.A. Michiedz'k, Homel 2009, cz. 2, s. 129-137; Eadem, Hramadski status sialankiu Biełarusi u pierszaj treci XX st., „Wiesci BDPU”, seria 2: Historyja, fiłasofija, palitałohija, sacyjałohija, ekanomika, kulturałohija, Minsk 2010, nr 2, s. 19-22; Por. I.W. Romanienko, Transformacyja statusa biełorusskoj sielskoj żenszcziny $w X X$ - naczale XXI w., Minsk 2015.

${ }^{16}$ I. Kurkow, Żenszcziny Biełarusi w „epochu kołlektiwizacyi” (po dokumientam CK KPB), „Diedy: Dajdżest publikacyj o biełorusskoj istorii” 2010, t. 5, s. 104109. 
Łaurynouskiej analizowane były przemiany w statusie społecznym kobiety na przełomie XIX i XX w., działalność zebrań delegatek w okresie międzywojennym, skład społeczny działaczek i polityka organizacji partyjnych. W swych publikacjach autorka zaznacza, że oprócz zebrań delegatek kobiety działały w takich organizacji społecznych jak „Stowarzyszenie Czerwonego Krzyża”"17, „Zwiazek Wojujacych Bezbożników”, „Precz z analfabetyzm”. Badaczka doszła do wniosku, że niezależnie od statusu społecznego kobiet w miastach i na wsi w pierwszym trzydziestoleciu XX w., kobiety nie odgrywały znacznej roli w życiu społeczno-politycznym Białorusi. Porównując mieszkanki miast i wsi, Łaurynouska zaznacza jednak, że w odróżnieniu od mieszkanek miasta, które były bardziej wykształcone i aktywne, chłopki były przeważnie niepiśmienne i negatywnie reagowały na próby ich aktywizacji.

Z kolei Kurkou pisał, że państwo chciało widzieć w kobietach swoich politycznych sprzymierzeńców. W odróżnieniu od wskazanych wyżej autorów uważa on, że powstałe w latach dwudziestych organizacje kobiet były niesamodzielne, nie można więc mówić o możliwości jakiejkolwiek „autonomii kobiet” w tamtych czasach. Jednocześnie dostrzega, że organizacje kobiece nie zawsze były nośnikami polityki KPB do własnych środowisk. Kierownictwo partii w pewnym momencie nie zauważyło, że w praktyce organizacje te odsunęły sprawy ideologiczne na drugi plan i zajmowały się problemami socjalnymi. Sekretarze partii, podkreśla Kurkou, bali się, że wydziały kobiece moga stać się postrzegane na wsi jako obrońcy przed polityka władz sowieckich ${ }^{18}$.

Większość badaczy okresu międzywojennego przeważnie zwracała uwage na działalność wydziałów kobiecych oraz zebrania delegatek. Problem udziału kobiet w innych organizacjach i ruchach społecznych (np. stachanowskim) pozostaje praktycznie nie zbadany.

\footnotetext{
$\overline{17}$ Krótki opis działalności kobiet $\mathrm{w}$ tej organizacji przedstawia: R.W. Timofiejewa, A.W. Paszuto, Rol żenszcziny $w$ diejatielnosti obszczestwiennych organizacyj Biełarusi [w:] Giendier i problemy kommunikatiwnogo powiedienija, Nowopołock 2013, s. 100-101.

18 I. Kurkow, op. cit., s. 204, 207.
} 
Udział kobiet w wydarzeniach Wielkiej Wojny Ojczyźnianej w białorusko-sowieckiej historiografii był opisywany pod katem ich pracy albo uczestnictwa w ruchu oporu ${ }^{19}$. Współcześni białoruscy badacze zaznaczaja, że w czasie wojny kobiety działały przeważnie $z$ motywów patriotycznych, a za miernik ich wkładu w walkę z Niemcami uważają odznaczenie dziewięciu białoruskich kobiet najwyższą sowiecka nagroda - Bohatera Związku Sowieckiego ${ }^{20}$.

Historycy zwracają także uwagę na obecność białoruskiego proniemieckiego nurtu narodowego na okupowanym terytorium Białorusi. Chociaż w jego składzie był wyraźny czynnik organizacji kobiecych, to problem ten jest najczęściej pomijany ${ }^{21}$, a działalność kobiet przedstawia się przeważnie w ogólnym kontekście. Wyjątkiem sa prace Iryny Nikałajewej o losie kobiet w latach Wielkiej Wojny Ojczyźnianej ${ }^{22}$. Zaznacza ona, że najpierw władze niemieckie nie planowały współpracy $z$ miejscową ludnością $\mathrm{w}$ zakresie politycznym, jednak porażki na froncie wschodnim zmusiły je do zmiany stosunku wobec miejscowej ludności, wśród której przeważały kobiety. Przejawem tego stała się próba stworzenia we współpracy z białoruskimi kolaborantami organizacji kobiecych ${ }^{23}$. Wynikiem tego typu działalności stało się powołanie w maju 1942 r. przy Białoruskiej Samopomocy Ludowej Ogólnobiałoruskiego Komitetu Kobiecego, na czele którego stanęła H. Wojtańczyszka. Głównym

19 Zob. np.: W. Murmancewa, Sowietskije żenszcziny $w$ Wielikoj Otieczestwiennoj wojnie, 1941-1945, Moskwa 1979.

${ }^{20}$ K.I. Kazak, Żenszcziny Giermanii $i$ Biełarusi w wojnie. Socyalizacyja obraza i jego wosprijatije [w:] Żanczyny u Druhoj suswietnaj wajnie: historyja baraćby $i$ wyżywannia, red. W.F. Bałakiraw [et al.], Minsk 2006, s. 55.

${ }^{21}$ A. Kawalenia, Prahiermanskija sajuzy moładzi na Biełarusi. 1941-1944. Wytoki. Struktura. Dziejnasć, Minsk 1999; Ł. Jurewicz, Wyrwanyja baczyny. Da historyi Sajuza biełaruskaje moładzi, Minsk 2001.

${ }^{22}$ O losie kobiet podczas II wojny światowej pisze: I. Nikałajewa, Politika niemieckich okkupacyonnych włastiej $w$ Biełarusi $w$ otnoszenii żenskogo nasielenija (1941-1944 gg.), „Żenszcziny w istorii: wozmożnost' byt' uwidiennymi” 2004, nr 3, s. 255-268; Eadem, Żanczyny Biełarusi u pieryjad hiermanskaj akupacyi (19411944), Minsk 2006; Eadem, Kałabaracyjnyja żanoczyja arhanizacyi na akupawanaj terytoryi Biełarusi (1942-1944 hh.) [w:] Hramadskija ruchi i palitycznyja partyi u Biełarusi, red. I. Koukiel, Hrodna 2009, s. 342-346.

${ }^{23}$ I. Nikałajewa, Kałabaracyjnyja żanoczyja arhanizacyi..., s. 342-343. 
celem tej organizacji była praca nad podwyższeniem stanu świadomości narodowej kobiet i ogólnie społeczeństwa.

Wśród innych stowarzyszeń żeńskich badacze wymieniaja Zjednoczenie Sióstr Białoruskich (cel jego działalności polegał na okazaniu pomocy ofiarom wojny) i kobiecy wydział przy Zwiazku Młodzieży Białoruskiej (kierowniczka Nadzieja Abramawa). Historycy zgadzają się, że sprzeczny charakter niemieckiej polityki okupacyjnej doprowadził do braku szerokiego wsparcia tych organizacji wśród miejscowej ludności. Na przełomie lat 1943/1944 wydział kobiecy Związku Młodzieży Białoruskiej liczył 4362 kobiety, z których 2674 było w wieku 15-20 lat ${ }^{24}$. W tym samym czasie tylko w oddziałach partyzanckich na terytorium Białorusi znajdowało się ponad 45 tys. kobiet $^{25}$.

Wraz z nadejściem Armii Czerwonej działacze białoruskiego ruchu narodowego wyjechali na Zachód. Już na wychodźstwie wspominana wyżej Abramawa powołała Stowarzyszenie Kobiet Białoruskich, które prowadziło działalność dobroczynną. Literatura o powojennych białoruskich strukturach na emigracji jest dość duża, jednak informacji o działalności kobiet jest bardzo mało ${ }^{26}$. Obecnie nie sa prowadzone żadne badania o losach i działaniach pochodzacych $z$ Białorusi kobiet na wychodźstwie.

Prace o udziale kobiet $\mathrm{w}$ powojennej odbudowie państwa i ruchach społecznych miały przeważnie propagandowy charakter. Opisywano w nich pracowniczy wysiłek kobiet, który wynikał $z$ faktu ich równouprawnienia, a także zaangażowanie w organizacjach społecznych i politycznych czy uczestnictwo w kierowaniu państwem.

Prace naukowe dotyczące tamtego okresu sa nieliczne. Wśród nich należy wymienić rozprawę doktorska Hanny Grabionkinej o działalności KPB w sprawie aktywizacji udziału kobiet w odbudowie i rozwoju gospodarki narodowej w latach 1946-

\footnotetext{
24 Ibidem, s. 345.

25 K.I. Kazak, op. cit., s. 47.

26 Przykładowo: W. Kipiel, Biełarusy u ZSZA, wyd. 2, Minsk 2017, s. 254-255.
} 
$1950^{27}$ oraz jej artykuł o działalności wydziałów kobiecych, zebrań delegatek i rad kobiecych w zachodnich obwodach BSRS w latach 1946-195028. Na podstawie dokumentów archiwalnych autorka pokazała, że praca w zachodnich obwodach BSRS kopiowała formy pracy Białorusi sowieckiej $z$ lat dwudziestych. Głównym celem poczynań w tej sferze partii komunistycznej było włączenie kobiet Białorusi Zachodniej do procesu przemian społeczno-politycznych i budowy socjalizmu.

Częściowo kwestię tę podjęła Łaurynouskaja. Na podstawie dokumentów Narodowego Archiwum Republiki Białoruś opisała przemiany w statusie społecznym kobiet wiejskich Białorusi Zachodniej w okresie powojennym ${ }^{29}$.

Wskazane wyżej dzieła badaczy białoruskich pokazują miejsce tematyki kobiecej w białoruskiej historiografii. Autorzy ograniczali się jedynie do niewielkiego zakresu spraw zwiazanych $z$ szeroko rozumiana problematyka kobieca. Od czasu do czasu pojawiały się przyczynkarskie publikacje o działalności wybitnych kobiet, które brały udział w ruchu narodowym - Zośka Wieras ${ }^{30}$, Paluta Badunowa $^{31}$, Wiera Masłouskaja ${ }^{32}$, Paulina Miadziołka ${ }^{33}$, Magdale-

27 A.A. Griebienkina, Diejatielnost' Kompartii Biełorussii po wowleczeniju żenszczin $w$ wosstanowlenije $i$ dalniejszeje razwitije narodnogo choziajstwa w 1946-1950 gg., Minsk 1975.

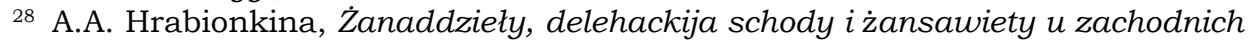
abłasciach BSSR (1946-1950 hh.), „Wiesci Akademii nawuk BSSR. Sieryja hramadskich nawuk" 1973, nr 6, s. 52-61.

${ }^{29}$ I. Ławrinowskaja, Osobiennosti socyalnogo statusa sielskoj żenszcziny $w$ Zapadnoj Biełarusi w poslewojennyj pieriod (wtoraja połowina 1940-ch - 1950-je gg.) [w:] Biełarus' waczyma polskich etnografau XIX - pierszaj pałowy XX st., Minsk 2013, s. 147-153.

${ }^{30}$ W. Skałaban, „Wam, jak historyku, nie zaszkodzić wiedać...”. Listy Zośki Wieras da Witala Skałabana. 1979-1988 hh., „Asoba i czas” 2009, t. 1, s. 172-207.

31 W. Lebiedziewa, Puciawinami zmahannia i pakutau: Pałuta Badunowa, Minsk 2004.

32 S. Rudowicz, Biełaruskaja żanczyna u wichury sacyjalnych uzruszenniau XX stahoddzia (na prykładzie losu Wiery Masłouskaj - rewalucyjanierki, paetesy, fieministki) [w:] Żenszczina. Obszczestwo. Obrazowanije, Minsk 2008, s. 353-362; J. Turonok, Niepokoriennaja Wiera, „Diedy: Dajdżest publikacyj o biełorusskoj istorii" 2011, t. 8, s. 148-156.

${ }_{33}$ P. Miadziołka, Scieżkami życcia, Minsk 1974. 
na Radziwiłł ${ }^{34}$ i in. ${ }^{35}$, w ruchu komunistycznym - Wiera Charużaja $^{36}$ czy o wykonawczyniach zamachu na niemieckiego komisarza generalnego Wilhelma Kube - Maryja Osipawa, Nadzieja Trajan, Alena Mazanik ${ }^{37} \mathrm{i}$ in.

W historiografii białoruskiej historia kobiet jako samodzielny kierunek badawczy zaczął się formować dopiero w połowie lat dziewięćdziesiątych, lecz nie cieszy się on nadmierna popularnością wśród uczonych. Nawet problem udziału kobiet w życiu społecznym BSRS w historiografii białoruskiej jest przedstawiony tylko fragmentarycznie. Najlepiej jest zbadana problematyka kobieca pierwszej połowy XX stulecia, lecz i w tym przypadku można mówić jedynie o przyczynkowości. Do tej pory nie powstała żadna publikacja na temat udziału kobiet w ruchu stachanowskim, w zwiazkach zawodowych, organizacjach społecznych, których działalność w mniejszym stopniu ukierunkowana była na upowszechnianie ideologii komunistycznej.

\section{Bibliografia}

\section{Źródła}

Miadziołka Paulina, Scieżkami życcia [uspaminy], Minsk : Mastackaja litaratura, 1974.

Skałaban Wital, „Wam, jak historyku, nie zaszkodzić wiedać...”. Listy Zośki Wieras da Witala Skałabana. 1979-1988 hh., „Asoba i czas” 2009, t. 1, s. 172-207, ISSN 2218-2039.

\footnotetext{
${ }^{34}$ A. Nadsan, Kniahinia Radziwił $i$ sprawa adradżennia unii u Biełarusi, Minsk 2006; A. Cyrkunou, Partret kniahini Mahdaleny Radziwił [w:] Aswietnica i miecenatka: da 150-hoddzia Mahdaleny z Zawiszau Radziwił, Minsk 2013, s. 48-50; I. Bahdanowicz, Mahdalena Radziwił i nacyjanalnaje adradżennie, "Maładosć" 2012, nr 4, s. 96-99.

35 A. Czarniakiewicz, Postaci biełaruskaha nacyjanalnaha ruchu u Hrodnie, 19091939 hh. (Bijahraficzny dawiednik), red. I. Koukiel, Minsk 2003.

36 Sławnaja docz biełorusskogo naroda: pis'ma, statji o Wierie Chorużej i wospominanija o niej, oprac. N.S. Oriechwo, I.P. Chowratowicz, Minsk 1960; G. Bułackij, Wiera Chorużaja - riewolucyonier, publicyst, Minsk 1973.

37 W. Sielemieniew, W. Szymolin, Ochota na gaulajtiera, Minsk 2006.
} 


\section{Opracowania}

Bahdanowicz Iryna, Mahdalena Radziwił i nacyjanalnaje adradżennie, „Maładosć” 2012, nr 4, s. 96-99, ISSN 0131-2308.

Bobkowa Taisija G., Diejatielnost' KPB po razwitiju trudowoj $i$ obszczestwienno-politiczeskoj aktiwnosti żenszczin $w$ wosstanowitielnyj pieriod (1921-1925 gg.), Minsk 1983.

Bułackij Grigirij, Wiera Chorużaja - riewolucyonier, publicyst, Minsk : BGU, 1973.

Centr giendiernych issledowanij Jewropiejskogo gosudarstwiennogo uniwiersitieta: http://bit.ly/2hIUULA.

Cyrkunou Aleś, Partret kniahini Mahdaleny Radziwił [w:] Aswietnica i miecenatka : da 150-hoddzia Mahdaleny z Zawiszau Radziwit, Minsk : Knihazbor, 2013, s. 48-50, ISBN 978-985-7057-33-7.

Czarniakiewicz Andrej, Postaci biełaruskaha nacyjanalnaha ruchu u Hrodnie, 1909-1939 hh. (Bijahraficzny dawiednik), red. Iwan Koukiel, Minsk : Hramadskaje abjadnannie „WIT”, 2003.

Czikałowa Irina, Intiegracyja giendiernoj problematiki $w$ biełorusskoje akadiemiczeskoje prostranstwo: niekotoryje priedwaritielnyje itogi [w:] Żenszczina. Obszczestwo. Obrazowanije, Minsk : Żenskij institut „Enwiła” 2008, s. 30-42, ISBN 978-985-6517-44-3.

Diubakowa Marija G., Bor'ba Kommunisticzeskoj partii Biełorussii za wowleczenije żenszczin riespubliki w promyszlennuju i obszczestwienno-politiczeskuju diejatielnost' (1926-1932 gg.), Minsk 1961.

Dułau Anatol M., Stanowiszcza żanczyn u BSSR 1920-1930-ch hh.: biełaruskaja histaryjahrafija, „Wiesnik Wiciebskaha dziarżaunaha uniwiersiteta imia P. M. Maszerawa” 2002, nr 2, s. 12-16, ISSN 20748566.

Dułow Anatolij N., Dielegatskije sobranija kak sriedstwo politiczeskoj socyalizacyi żenszczin Sowietskoj Biełorussii (1920-je - naczało 1930-ch gg.), „Uczenyje zapiski Uczrieżdienija obrazowanija "WGU im. P.M. Maszerowa”" 2009, t. 8, s. 19-30, ISSN 2075-1613.

Dułow Anatolij N., Stanowlenije i razwitije żenskogo dwiżenija w BSSR $w$ mieżwojennyj pieriod [w:] Hramadskija ruchi i palitycznyja partyi u Biełarusi, red. Iwan Koukiel, Hrodno : HrDU, 2009, s. 202-206, ISBN 978-985-515-200-3. 
Dułow Anatolij N., Stanowlenije żenskogo dwiżenija w BSSR (1920-je gg.) [w:] Giendier i problemy kommunikatiwnogo powiedienija, Połock : PGU, 2007, s. 78-79, ISBN 978-985-418-252-0.

Dułow Anatolij N., Żenszcziny Sowietskoj Biełarusi w obszczestwienno-politiczeskoj żyzni i matierialnom proizwodstwie (20-je gody XX wieka), Minsk 2006.

Griebienkina Anna A., Diejatielnost' Kompartii Biełorussii po wowleczeniju żenszczin $w$ wosstanowlenije $i$ dalniejszeje razwitije narodnogo choziajstwa w 1946-1950 gg., Minsk 1975.

Histaryjahrafija historyi Biełarusi kanca XVIII - paczatku XX: zdabytki, prablemy, pierspiektywy, red. W.W. Janouskaja, Minsk : Biełaruskaja nawuka, 2006, ISBN 985-08-0761-X.

Hrabionkina Anna A., Żanaddzieły, delehackija schody $i$ żansawiety u zachodnich abłasciach BSSR (1946-1950 hh.), „Wiesci Akademii nawuk BSSR. Sieryja hramadskich nawuk" 1973, nr 6, s. 52-61, ISSN 03211649.

Jakiełla Albiert, Giendiernaja istorija $w$ biełorusskoj istoriografii. Wozniknowienije i razwitije, „Wiesnik Hrodzienskaha dziarżaunaha uniwiersiteta" 2007, seria 1, nr 3, s. 28-33, ISSN 2076-4839.

Jakowlewa Galina N., Dułow Anatolij N., Żenszcziny Witiebszcziny w pieriod modiernizacyi 1930-ch godow, „Żenszcziny w istorii: wozmożnost' byt' uwidiennymi" 2001, t. 1, s. 304-310, ISSN 985-435-359-1.

Jurewicz Lawon, Wyrwanyja baczyny. Da historyi Sajuza biełaruskaje moładzi, Minsk : Encykłapiedyks, 2001, ISBN 985-6599-24-5.

Kawalenia Alaksandr, Prahiermanskija sajuzy moładzi na Biełarusi. 1941-1944. Wytoki. Struktura. Dziejnasć, Minsk : BDPU, 1999, ISBN 985-435-131-9.

Kazak Kuz'ma I., Żenszcziny Giermanii i Biełarusi w wojnie. Socyalizacyja obraza i jego wosprijatije [w:] Żanczyny u Druhoj suswietnaj wajnie: historyja baraćby $i$ wyżywannia, red. W.F. Bałakiraw [et al.], Minsk 2006, s. 7-56.

Kipiel Witaut, Biełarusy u ZSZA, wyd. 2, Minsk : Knigazbor, 2017, ISBN 978-985-7080-20-2.

Komarow Albiert, Nowyje jawlenija $w$ obszczestwiennom i siemiejnom bytu trudiaszczichsia Sowietskoj Biełorussii (1917-1929 gg.), Minsk 1969. 
Kurkow Ilja, Żenszcziny Biełarusi $w$ „epochu kołlektiwizacyi” (po dokumientam CK KPB), „Diedy: Dajdżest publikacyj o biełorusskoj istorii” 2010, t. 5, s. 104-109, ISBN 978-985-16-9244-2.

Lebiedziewa Walancina, Puciawinami zmahannia i pakutau: Pałuta Badunowa, Minsk : Technałogiia, 2004, ISBN 985-458-094-6.

Łaurynouskaja Irina, Hramadski status sialankiu Biełarusi u pierszaj treci XX st., „Wiesci BDPU”, seria 2: Historyja, fiłasofija, palitałohija, sacyjałohija, ekanomika, kulturałohija, Minsk 2010, nr 2, s. 19-22, ISSN 1818-8583.

Ławrinowskaja Irina, Obszczestwiennyj status żenszcziny w Biełarusi w pierwoj trieti XX wieka [w:] Biełarus' u histarycznaj retraspiektywie XIX-XX stahoddziau: etnakulturnyja i nacyjanalna-dziarżaunyja pracesy: zbornik nawukowych artykułau: $w 2$ czast., red. W.A. Michiedźk, Homel : HDU, 2009, cz. 2, s. 129-137, ISBN 978-985-439-446-6.

Ławrinowskaja Iryna, Osobiennosti socyalnogo statusa sielskoj żenszczi$n y w$ Zapadnoj Biełarusi $w$ poslewojennyj pieriod (wtoraja połowina 1940-ch - 1950-je gg.) [w:] Biełarus' waczyma polskich etnografau XIX - pierszaj pałowy XX st., Minsk: W. Chursik, 2013, s. 147-153, ISBN 978-985-7025-22-0.

Ławrinowskaja Irina W., Transformacyja obszczestwiennogo statusa sielskoj żenszcziny $w$ Biełarusi wo wtoroj połowinie XX - naczale XXI $w$. [w:] Pytanni mastactwaznaustwa, etnałohii i falkłarystyki, red. A. A1fiorow, Minsk : Prawa i ekanomika, 2010, t. 9, s. 305-310, ISBN 978985-442-893-2.

Murmancewa W., Sowietskije żenszcziny $w$ Wielikoj Otieczestwiennoj wojnie, 1941-1945, wyd. 2, Moskwa : Mys1, 1979.

Nadsan Alaksandar, Kniahinia Radziwił $i$ sprawa adradżennia unii u Bietarusi, wyd. 2, Minsk 2006.

Nikałajewa Iryna, Kałabaracyjnyja żanoczyja arhanizacyi na akupawanaj terytoryi Biełarusi (1942-1944 hh.) [w:] Hramadskija ruchi i palitycznyja partyi u Biełarusi, red. Iwan Koukiel, Hrodno : HrDU, 2009, s. 342-346, ISBN 978-985-515-200-3.

Nikałajewa Iryna, Żanczyny Biełarusi u pieryjad hiermanskaj akupacyi (1941-1944), Minsk 2006. 
Nikałajewa Irina, Politika niemieckich okkupacyonnych włastiej w Biełarusi $w$ otnoszenii żenskogo nasielenija (1941-1944 gg.), „Żenszcziny w istorii : wozmożnost' byt' uwidiennymi" 2004, nr 3, s. 255-268.

Portnowa Maija S., Diejatielnost' Kompartii Biełorussii po wowleczeniju żenszczin dieriewni $w$ kołchoznoje stroitielstwo (1929-1934 gg.), Minsk 1972.

Romanienko Irina W., Transformacyja statusa biełorusskoj sielskoj żenszcziny $w X X-$ naczale XXI $w$., Minsk : Biełaruskajanawuka, 2015, ISBN 978-985-08-1901-7.

Rudowicz Stanisłau, Biełaruskaja żanczyna u wichury sacyjalnych uzruszenniau XX stahoddzia (na prykładzie losu Wiery Masłouskaj - rewalucyjanierki, paetesy, fieministki) [w:] Żenszczina. Obszczestwo. Obrazowanije, Minsk : BGPU im. M. Tanka, 2008, s. 353-362, ISBN 978-985-6517-44-3.

Sielemieniew Wiaczasław, Szymolin Wiktor, Ochota na gaulajtiera, Minsk : Nacyonalnyj archiw Riespubliki Biełarus', 2006, ISBN 985-6372-445.

Skułak N.O., Istorija żenszczin Biełarusi $w$ sowriemiennoj otieczestwiennoj istoriografii [w:] Giendier i problemy kommunikatiwnogo powiedienija, Połock: PGU, 2005, s. 42-44, ISBN 985-418-228-2.

Sławnaja docz biełorusskogo naroda: pis'ma, statji o Wierie Chorużej i wospominanija o niej, oprac. N.S. Oriechwo, I.P. Chowratowicz, Minsk : Gosudarstwiennoje izdatielstwo BSSR, 1960.

Sorokina W.W., Rol żenszczin-kriestjanok $w$ obszczestwienno-politiczeskoj i kulturnoj żyzni biełorusskoj dieriewni $w$ wosstanowitielnyj pieriod (1921-1925 gg.), Minsk 1958.

Sorokina W.W., Wowleczenije żenszczin-kriestjanok $w$ obszczestwienno-politiczeskuju żyzn' biełorusskoj dieriewni w wosstanowitielnyj pieriod (1921-1925 gg.), „Uczenyje zapiski Minskogo piedagogiczeskogo instituta im. A.M. Gor'kogo" 1957, t. 8, s. 23-47.

Timofiejewa R.W., Paszuto A.W., Rol żenszcziny $w$ diejatielnosti obszczestwiennych organizacyj Biełarusi [w:] Giendier i problemy kommunikatiwnogo powiedienija, Nowopołock : PGU, 2013, s. 100-101, ISBN 978-985-531-420-3.

Turonok Jurij, Niepokoriennaja Wiera, „Diedy: Dajdżest publikacyj o biełorusskoj istorii” 2011, t. 8, s. 148-156, ISBN 978-985-18-0579-8. 
Us Aleksandra, Szto dała Kastrycznickaja rewalucyja żanczynam Biełarusi, Minsk 1958.

Us Aleksandra, Żenszcziny sowietskoj Biełorussii, Minsk 1948.

$W$ bor'bie i trudie: uczastije żenszczin Biełorussii $w$ riewolucyonnom dwiżenii, socyalisticzeskom i kommunisticzeskom stroitielstwie, red. T.T. Dmitrijewa, Minsk : Biełarus', 1977.

Zachwatajewa Elena N., Proizwodstwiennaja i obszczestwienno-politiczeskaja diejatielnost'żenszczin Sowietskoj Biełorussii w gody wtoroj piatiletki (1933-1937 gg.), Minsk 1958.

Zachwatajewa Elena N., Żenszcziny Sowietskoj Biełorussii - aktiwnyje stroitieli kommunizma, Minsk : Prawlenije Obszczestwa po rasprostranieniju politiczeskich i naucznych znanij BSSR, 1960.

Żenszcziny Biełarusi $w$ zierkale epochi: nacyonalnyj otczet, Minsk 1997, ISBN 985-6355-04-4.

Żenszcziny na kraju Jewropy, red. E. Gapowa, Minsk : EGU, 2003, ISBN 985-6723-12-4.

Żenszcziny $w$ istorii: wozmożnost' byt' uwidiennymi, red. I. Czikałowa, Minsk : BGPU im. M. Tanka, 2001-2004, t. 1-3, ISBN 985-435-359-1. 